\title{
Instrumen Penilaian Mata Pelajaran Pendidikan Jasmani Olahraga dan Kesehatan Pada Siswa SMP: A Systematic Review
}

\author{
${ }^{1}$ Wahyu Firmansyah, ${ }^{2}$ Advendi Kristiyandaru, ${ }^{3}$ Achmad Widodo \\ Prodi S2 Pendidikan Olahraga, Pascasarjana Universitas Negeri Surabaya \\ mohwahyuf@gmail.com
}

\begin{abstract}
Assessment in PJOK learning provides information on changes in the progress or decline in skills of students' skills. The assessment of PJOK can be carried out in the cognitive, psychomotor, and affective domains. This assessment provides space for students who have a tendency towards non-academic weaknesses in sports skills. The research objective was to obtain information related to the assessment of PJOK learning at the junior high school level. The review method chosen was to obtain research journals with the keyword assessment of PJOK SMP or assessment instruments in physical education at Google Scholar reference sources, sciencedirect, and research gate. 12 journals have been reviewed based on reference sources, samples, research methods, types of instruments and findings. The results of the assessment show that the assessment of PJOK can be carried out based on the context you want to assess, cognitive, psychomotor, and affective aspects. The cognitive aspect assessment instrument can be seen, the psychomotor aspect is in the form of an assessment rubric, and the affective aspect can be in the form of an essay.
\end{abstract}

Keywords: Assessment Instruments PJOK, Junior High School Students.

Abstrak. Penilaian dalam pembelajaran PJOK memberikan informasi terkait perubahan kemajuan atau kemunduran keterampilan gerak peserta didik. Penilaian PJOK dapat dilakukan dalam ranah kognitif, psikomotorik, dan afektif. Penilaian tersebut memberikan ruang bagi peserta didik yang memiliki kecenderungan kelemahan non akademis dalam keterampilan gerak olahraga. Tujuan penelitian untuk mendapatkan informasi terkait instrumen penilaian pembelajaran PJOK pada tingkat sekolah menengah pertama. Metode review dipilih untuk mendapatkan jurnal penelitian dengan kata kunci instrumen penilaian PJOK SMP atau assessment instrument in physical education pada sumber rujukan google scholar, sciencedirect, dan research gate. 12 jurnal telah direview berdasarkan sumber rujukan, sampel, metode penelitian, jenis instrumen dan hasil temuan. Hasil review menunjukkan bahwa instrumen penilaian PJOK dapat dilakukan berdasarkan konteks yang ingin dinilai, aspek kognitif, psikomotorik, dan afektif. Instrumen penilaian pada aspek kognitif dapat berupa pengamatan, aspek psikomotorik berupa rubrik penilaian gerak, sedangkan aspek afektif dapat berupa soal essay.

Keywords: Instrumen Penilaian, Siswa Sekolah Menengah Atas.

\section{PENDAHULUAN}

Instrumen penilaian pada pembelajaran PJOK ditemukan banyak yang belum memenuhi kriteria penilaian. Aji dan Winarno (2016) menemukan bahwa instrumen penilaian pengetahuan pada PJOK memiliki performa $75 \%$ soal tidak valid dengan tingkat reliabilitas soal sebesar 0,46 (masuk pada kategori cukup) dari hasil observasi. Temuan tersebut diperkuat dari hasil wawancara dengan guru PJOK yang menyebutkan bahwa instrumen penilaian hanya sebatas dibuat tanpa dianalisis tingkat validitas, reliabilitas, tingkat kesukaran, dan sebaran ranah pengetahuan. Ashari dan Djunaidi (2016) menemukan beberapa kendala dalam melakukan penilaian unjuk kerja (performance) pada pembelajaran PJOK, di antaranya: instrumen penilaian tidak dilengkapi dengan pedoman range skor; proses penilaian masih subjektivitas, karena tidak ada persyaratan validitas, reliabilitas, keefektifan, dan kepraktisan; dan guru jarang memperhatikan riwayat penilaian siswa terdahulu, sehingga guru tidak mampu melihat perkembangan siswa dalam belajar. Selanjutnya Aswin dan Winarno (2016) juga menemukan bahwa ada beberapa soal dari instrumen penilaian pembelajaran PJOK yang didasarkan pada kompetensi dasar pada kurikulum 2013. Paria dan Djunaidi (2016) juga menunjukkan bahwa kelemahan penilaian pada pembelajaran PJOK terletak pada hasil praktisi siswa. Bahkan, Kurniawan, dkk (2018) menyampaikan bahwa evaluasi pembelajaran PJOK harus dilakukan secara menyeluruh, tidak hanya pada proses penilaian. Beberapa penelitian di atas menunjukkan bahwa ada kendala yang harus 
segera diselesaikan, khususnya pada instrumen penilaian pembelajaran PJOK.

Penilaian dalam PJOK merupakan kegiatan yang dilakukan oleh seorang guru PJOK setelah menyelesaikan pembelajaran tertentu, sehingga dari hasil kegiatan tersebut dapat menjadi tolak ukur dalam menyelenggarakan pembelajaran PJOK selanjutnya (Arifin, 2009). Poerwanti (2010) menyebutkan bahwa tujuan diselenggarakan penilaian dalam pembelajaran PJOK agar guru mengetahui perkembangan siswa setelah mempelajari materi tertentu, khususnya dalam keterampilan gerak olahraga. Mutu pembelajaran PJOK diukur melalui proses hingga penilaian dalam pembelajaran dengan adanya perubahan pada perkembangan gerak pada peserta didik. Kurniawan, dkk (2018) menemukan bahwa pembelajaran PJOK yang diselenggarakan belum memenuhi kriteria mulai dari proses pembelajaran hingga penilaian. Kendala pada proses pembelajaran terdapat pada sarana prasarana yang belum menunjang, mayoritas siswa duduk dan diam selama pembelajaran, dan guru tidak melakukan kegiatan belajar mengajar. Kendala pada proses penilaian terletak pada instrumen penilaian yang digunakan dan terkadang hanya dilakukan pada ranah kemampuan gerak (keterampilan saja). Hal ini menjadi fokus permasalahan dalam penelitian review ini, karena instrumen penilaian dalam pembelajaran dapat ditempuh secara kognitif, psikomotorik, dan afektif. Masing-masing ranah penilaian memiliki karakteristik tujuan tersendiri. Ketiga penilaian tersebut harus dilakukan, mengingat setiap peserta didik memiliki kelemahan dan kelebihan, artinya ada peserta didik yang unggul dalam bidang akademis namun lemah non akademis maupun sebaliknya. Oleh karena itu, perlu dilakukan penelitian dengan teknik review untuk menganalisis ranah penilaian dalam pembelajaran PJOK.

\section{METODE}

Metode review dipilih dalam penelitian ini bertujuan untuk mencari artikel ilmiah tentang penelitian deskriptif, eksperimen, penelitian pengembangan, dan atau studi kepustakaan, kemudian dilakukan review atas artikel ilmiah yang telah kumpulkan untuk dilakukan pengambilan kesimpulan terhadap tema penelitian. Proses review artikel pada penelitian ini membahas tentang instrumen penilaian mata pelajaran pendidikan jasmani olahraga kesehatan pada siswa SMP.

Artikel ilmiah yang telah dikumpulkan oleh peneliti berasal dari google scholar, sciencedirect, dan research gate dengan kata kunci instrumen penilaian PJOK dan atau assessment instrument in physical education. Artikel yang dipilih dari referensi 10 tahun terakhir dan berfokus pada kata kunci yang telah ditetapkan Teknik analisa jurnal menggunakan matriks sintesis dengan membuat sebuah tabel yang terdiri dari kolom sumber rujukan dan hasil temuan. berikut adalah ilustrasi matriks sintesis dari proses review:

Tabel 1. Format Review Jurnal

\begin{tabular}{|l|l|l|l|}
\hline $\begin{array}{c}\text { Sumber } \\
\text { Rujukan }\end{array}$ & Sampel & $\begin{array}{c}\text { Metode } \\
\text { penelitian }\end{array}$ & $\begin{array}{c}\text { Hasil } \\
\text { temuan } \\
\text { review }\end{array}$ \\
\hline Sumber 1 & & & \\
\hline Sumber 2 & & & \\
\hline Sumber 3 & & & \\
\hline Sumber 4 & & & \\
\hline Sumber 5 & & & \\
\hline Dst & & & \\
\hline
\end{tabular}

\section{HASIL}

Proses review dilakukan pada artikel ilmiah yang telah dipilih berdasarkan rujukan, sampel, metode penelitian, dan hasil temuan. Total ada 12 jurnal telah di review. Berikut proses review jurnal pada penelitian ini:

Tabel 2. Review jurnal

\begin{tabular}{|c|c|c|c|c|}
\hline $\begin{array}{c}\text { Sumber } \\
\text { Rujukan }\end{array}$ & Sampel & $\begin{array}{c}\text { Metode } \\
\text { Penelitian }\end{array}$ & $\begin{array}{c}\text { Fokus } \\
\text { penelitian }\end{array}$ & $\begin{array}{c}\text { Hasil } \\
\text { Temuan }\end{array}$ \\
\hline $\begin{array}{l}\text { Aji, } \\
\text { Bastaman } \\
\text { Sasmito dan } \\
\text { M. E. } \\
\text { Winarno } \\
\text { (2016) }\end{array}$ & $\begin{array}{l}30 \text { sampel } \\
\text { pada uji } \\
\text { coba } \\
\text { kelompok } \\
\text { kecil dan } \\
60 \text { sampel } \\
\text { pada uji } \\
\text { coba } \\
\text { kelompok } \\
\text { besar }\end{array}$ & $\begin{array}{l}\text { Metode } \\
\text { penelitian } \\
\text { pengembanga } \\
\text { n. Data } \\
\text { diperoleh } \\
\text { secara } \\
\text { kualitatif dan } \\
\text { kuantitatif. } \\
\text { Analisis data } \\
\text { menggunakan } \\
\text { program } \\
\text { aplikasi } \\
\text { statistik } \\
\text { meliputi } \\
\text { validitas, } \\
\text { reliabilitas, } \\
\text { tingkat } \\
\text { kesukaran } \\
\text { soal, dan daya } \\
\text { beda. }\end{array}$ & $\begin{array}{l}\text { Instrumen } \\
\text { penilaian } \\
\text { aspek } \\
\text { pengetahuan } \\
\text { PJOK }\end{array}$ & $\begin{array}{l}\text { Instrumen } \\
\text { penilaian } \\
\text { pada aspek } \\
\text { pengetahua } \\
\text { n mata } \\
\text { pelajaran } \\
\text { pendidikan } \\
\text { jasmani } \\
\text { olahraga } \\
\text { dan } \\
\text { kesehatan } \\
\text { pada } \\
\text { jenjang } \\
\text { menengah } \\
\text { pertama } \\
\text { direkomen } \\
\text { dasikan } \\
\text { dalam } \\
\text { bentuk } \\
\text { multimedia } \\
\text { interaktif } \\
\text { dengan }\end{array}$ \\
\hline
\end{tabular}


Terakreditasi Peringkat 4 (No. SK: 36/E/KPT/2019)

\begin{tabular}{|c|c|c|c|c|}
\hline & & & & $\begin{array}{l}\text { menggunak } \\
\text { an program } \\
\text { wondersha } \\
\text { re quiz } \\
\text { creator. }\end{array}$ \\
\hline $\begin{array}{l}\text { Akbar, M. } \\
\text { Army., } \\
\text { Rahmadi, } \\
\text { dan Mulhim } \\
(2020)\end{array}$ & $\begin{array}{l}7 \text { pendidik } \\
\text { pada } 7 \\
\text { instansi } \\
\text { pendidika } \\
\text { n negeri } \\
\text { yang } \\
\text { berbeda }\end{array}$ & $\begin{array}{l}\text { Penelitian } \\
\text { menggunakan } \\
\text { jenis } \\
\text { penelitian } \\
\text { survei dengan } \\
\text { metode } \\
\text { kuantitatif. }\end{array}$ & $\begin{array}{l}\text { Instrumen } \\
\text { penilaian } \\
\text { aspek } \\
\text { psikomotor } \\
\text { PJOK }\end{array}$ & $\begin{array}{l}\text { Instrumen } \\
\text { penilaian } \\
\text { aspek } \\
\text { psikomotor } \\
\text { dapat } \\
\text { dilakukan } \\
\text { melalui } \\
\text { penilaian } \\
\text { proyek dan } \\
\text { penilaian } \\
\text { kinerja } \\
\text { yang } \\
\text { dituangkan } \\
\text { pada rubrik } \\
\text { penilaian } \\
\text { kinerja } \\
\text { yang } \\
\text { berisikan } \\
\text { instruksi } \\
\text { untuk } \\
\text { melakukan } \\
\text { gerakan } \\
\text { berdasarka } \\
\text { n } \\
\text { kompetensi } \\
\text { dasar yang } \\
\text { di ajarkan. }\end{array}$ \\
\hline $\begin{array}{l}\text { Ashari, Lalu } \\
\text { Hassan dan } \\
\text { Djuniadi } \\
\text { (2016) }\end{array}$ & $\begin{array}{l}20 \text { sampel } \\
\text { pada uji } \\
\text { coba } \\
\text { kelompok } \\
\text { kecil dan } \\
74 \text { sampel } \\
\text { pada uji } \\
\text { coba } \\
\text { kelompok } \\
\text { besar }\end{array}$ & $\begin{array}{l}\text { Metode } \\
\text { penelitian } \\
\text { pengembanga } \\
\mathrm{n} \text {. Analisis } \\
\text { data } \\
\text { menggunakan } \\
\text { formula } \\
\text { Aikens's } V, \\
\text { product } \\
\text { momen, alpha } \\
\text { cronchbach, } \\
\text { dan T skor }\end{array}$ & $\begin{array}{l}\text { Instrumen } \\
\text { penilaian per } \\
\text { assessment } \\
\text { system }\end{array}$ & $\begin{array}{l}\text { Instrumen } \\
\text { penilaian } \\
\text { per } \\
\text { assessment } \\
\text { system } \\
\text { merubah } \\
\text { fungsi guru } \\
\text { sebagai } \\
\text { fasilitator } \\
\text { dan } \\
\text { motivator, } \\
\text { sedangkan } \\
\text { menempatk } \\
\text { an siswa } \\
\text { sebagai } \\
\text { penilai. } \\
\text { Peer } \\
\text { assessment } \\
\text { system } \\
\text { berbentuk } \\
\text { penilaian } \\
\text { ceklis } \\
\text { dengan } \\
\text { empat } \\
\text { skala yang } \\
\text { dikemas } \\
\text { dalam } \\
\text { bentuk } \\
\text { spread } \\
\text { sheet. } \\
\text { Penilaian } \\
\text { tersebut } \\
\text { dilengkapi } \\
\text { dengan } \\
\text { rubrik } \\
\text { analitik dan } \\
\text { pedoman } \\
\text { penskoran } \\
\text { dengan } \\
\text { bentuk } \\
\text { paper } \\
\text { based. }\end{array}$ \\
\hline $\begin{array}{l}\text { Garcia, et } \\
\text { al., (2020) }\end{array}$ & - & $\begin{array}{l}\text { A systematic } \\
\text { review }\end{array}$ & $\begin{array}{l}\text { Peer } \\
\text { assessment }\end{array}$ & $\begin{array}{l}\text { Penggunaa } \\
\mathrm{n} \text { penilaian } \\
\text { peer } \\
\text { assessment } \\
\text { meningkat } \\
\text { kan tingkat } \\
\text { motivasi } \\
\text { dan } \\
\text { kepercayaa } \\
\text { n mengajar }\end{array}$ \\
\hline $\begin{array}{l}\text { Irwanto } \\
(2019)\end{array}$ & $\begin{array}{l}\begin{array}{l}\text { Seluruh } \\
\text { guru }\end{array} \\
\end{array}$ & $\begin{array}{l}\text { Metode } \\
\text { deskriptif }\end{array}$ & $\begin{array}{l}\text { Instrumen } \\
\text { penilaian }\end{array}$ & $\begin{array}{l}\text { Instrumen } \\
\text { penilaian }\end{array}$ \\
\hline
\end{tabular}

\begin{tabular}{|c|c|c|c|c|}
\hline & $\begin{array}{l}\text { PJOK dan } \\
\text { siswa } \\
\text { sekolah }\end{array}$ & $\begin{array}{l}\text { kualitatif. } \\
\text { Instrumen } \\
\text { penelitian } \\
\text { berupa } \\
\text { angket, } \\
\text { kuesioner, } \\
\text { wawancara, } \\
\text { dan observasi }\end{array}$ & $\begin{array}{l}\text { model CIPP } \\
\text { (context, } \\
\text { input, } \\
\text { process, dan } \\
\text { product) }\end{array}$ & $\begin{array}{l}\text { model } \\
\text { CIPP } \\
\text { didasarkan } \\
\text { pada } \\
\text { variabel } \\
\text { context } \\
\text { (berhubung } \\
\text { an dengan } \\
\text { kebutuhan } \\
\text { dan tujuan } \\
\text { pembelajar } \\
\text { an), input } \\
\text { (berhubung } \\
\text { an dengan } \\
\text { SDM } \\
\text { sekolah } \\
\text { dan } \\
\text { sarpras), } \\
\text { process } \\
\text { (berhubung } \\
\text { an dengan } \\
\text { perencanaa } \\
\text { n, } \\
\text { pelaksanaa } \\
\text { n, dan } \\
\text { evaluasi } \\
\text { pembelajar } \\
\text { an), dan } \\
\text { product } \\
\text { (berhubung } \\
\text { an dengan } \\
\text { hasil } \\
\text { belajar, } \\
\text { meliputi } \\
\text { afektif, } \\
\text { psikomotor } \\
\text {, dan } \\
\text { kognitif) }\end{array}$ \\
\hline $\begin{array}{l}\text { Ismail, Indri } \\
\text { Astuti, dan } \\
\text { Aloysius } \\
\text { Mering } \\
(2018)\end{array}$ & $\begin{array}{l}9 \text { guru } \\
\text { PJOK, 48 } \\
\text { siswa, dan } \\
5 \text { wakil } \\
\text { kepala } \\
\text { sekolah } \\
\text { bidang } \\
\text { kurikulum }\end{array}$ & $\begin{array}{l}\text { Metode } \\
\text { deskriptif } \\
\text { kualitatif. } \\
\text { Pengumpulan } \\
\text { data } \\
\text { menggunakan } \\
\text { kuesioner, } \\
\text { wawancara, } \\
\text { observasi, dan } \\
\text { dokumentasi. }\end{array}$ & $\begin{array}{l}\text { Instrumen } \\
\text { penilaian } \\
\text { model CIPP } \\
\text { (context, } \\
\text { input, } \\
\text { process, dan } \\
\text { product) }\end{array}$ & $\begin{array}{l}\text { Model } \\
\text { CIPP } \\
\text { didasarkan } \\
\text { pada } \\
\text { penilaian } \\
\text { secara } \\
\text { keseluruha } \\
\text { n, mulai } \\
\text { dari tujuan } \\
\text { pembelajar } \\
\text { an, sarana } \\
\text { prasarana, } \\
\text { proses } \\
\text { pembelajar } \\
\text { an hingga } \\
\text { produk } \\
\text { atau hasil } \\
\text { dari } \\
\text { pembelajar } \\
\text { an. }\end{array}$ \\
\hline $\begin{array}{l}\text { Iswanto. } \\
\text { (2017) }\end{array}$ & $\begin{array}{l}12 \text { sekolah } \\
\text { menengah } \\
\text { pertama }\end{array}$ & $\begin{array}{l}\text { Penelitian } \\
\text { deskriptif } \\
\text { kualitatif - } \\
\text { kuantitatif } \\
\text { dengan } \\
\text { instrumen } \\
\text { pengumpulan } \\
\text { data berupa } \\
\text { check list }\end{array}$ & $\begin{array}{l}\text { Instrumen } \\
\text { penilaian } \\
\text { ujian formatif } \\
\text { pada aspek } \\
\text { kognitif dan } \\
\text { psikomotor } \\
\text { dengan } \\
\text { bentuk soal } \\
\text { essay dan } \\
\text { praktek }\end{array}$ & $\begin{array}{l}\text { Instrumen } \\
\text { penilaian } \\
\text { pada } \\
\text { pelajaran } \\
\text { PJOK } \\
\text { dapat } \\
\text { dilakukan } \\
\text { pada aspek } \\
\text { psikomotor } \\
\text { ik dengan } \\
\text { memberika } \\
\text { n tes } \\
\text { praktek, } \\
\text { sedangkan } \\
\text { pada ranah } \\
\text { kognitif } \\
\text { dapat } \\
\text { berupa soal } \\
\text { essay. }\end{array}$ \\
\hline $\begin{array}{l}\text { Juniarta, } \\
\text { Aswin Try } \\
\text { dan M. E. } \\
\text { Winarno } \\
\text { (2016) }\end{array}$ & $\begin{array}{l}20 \text { sampel } \\
\text { kelompok } \\
\text { kecil dan } \\
40 \text { sampel } \\
\text { kelompok } \\
\text { besar }\end{array}$ & $\begin{array}{l}\text { Metode } \\
\text { penelitian dan } \\
\text { pengembanga } \\
\mathrm{n}\end{array}$ & $\begin{array}{l}\text { Instrumen } \\
\text { penilaian } \\
\text { PJOK pada } \\
\text { aspek } \\
\text { pengetahuan }\end{array}$ & $\begin{array}{l}\text { Instrumen } \\
\text { penilaian } \\
\text { pelajaran } \\
\text { PJOK } \\
\text { dikemas } \\
\text { dalam } \\
\text { bentuk soal } \\
\text { online dan } \\
\text { direkomen }\end{array}$ \\
\hline
\end{tabular}


Terakreditasi Peringkat 4 (No. SK: 36/E/KPT/2019)

\begin{tabular}{|c|c|c|c|c|}
\hline & & & & $\begin{array}{l}\text { dasikan } \\
\text { melalui } \\
\text { program } \\
X A M P P .\end{array}$ \\
\hline $\begin{array}{l}\text { Kurniawan, } \\
\text { Robby., M. } \\
\text { E. Winarno., } \\
\text { dan Wasis } \\
\text { Djoko } \\
\text { Dwiyogo } \\
\text { (2018) }\end{array}$ & 8 sekolah & $\begin{array}{l}\text { Penelitian } \\
\text { evaluatif } \\
\text { dengan } \\
\text { metode } \\
\text { deskriptif } \\
\text { analitis }\end{array}$ & $\begin{array}{l}\text { Evaluasi } \\
\text { pembelajaran } \\
\text { model } \\
\text { Countenance }\end{array}$ & $\begin{array}{l}\text { Model } \\
\text { countenanc } \\
e \\
\text { didasarkan } \\
\text { pada tahap } \\
\text { penggamba } \\
\text { ran } \\
\text { (descriptio } \\
n \text { ) dan } \\
\text { pertimbang } \\
\text { an } \\
\text { (judgement } \\
\text { ). Setiap } \\
\text { tahap } \\
\text { tersebut } \\
\text { dibagi lagi } \\
\text { menjadi } \\
\text { tahapan } \\
\text { pendahulua } \\
\mathrm{n} \\
\text { (antecende } \\
\text { nt), proses } \\
\text { (transactio } \\
n \text { ), dan } \\
\text { hasil } \\
\text { (outcomes). }\end{array}$ \\
\hline $\begin{array}{l}\text { Patria, Lalu } \\
\text { Demung dan } \\
\text { Djuniadi. } \\
\text { (2016) }\end{array}$ & $\begin{array}{l}16 \text { sampel } \\
\text { kelompok } \\
\text { kecil dan } \\
31 \text { sampel } \\
\text { kelompok } \\
\text { besar }\end{array}$ & $\begin{array}{l}\text { Metode } \\
\text { penelitian dan } \\
\text { pengembanga } \\
\mathrm{n}\end{array}$ & $\begin{array}{l}\text { Instrumen } \\
\text { penilaian } \\
\text { psikomotor } \\
\text { berbasis IT }\end{array}$ & $\begin{array}{l}\text { Instrumen } \\
\text { penilaian } \\
\text { psikomotor } \\
\text { berbasis IT } \\
\text { dapat } \\
\text { diaplikasik } \\
\text { an pada } \\
\text { materi } \\
\text { PJOK } \\
\text { lompat } \\
\text { jauh. }\end{array}$ \\
\hline $\begin{array}{l}\text { Salasiah, } \\
\text { Rahmadi, } \\
\text { dan Tri } \\
\text { Irianto } \\
(2020)\end{array}$ & 7 sekolah & $\begin{array}{l}\text { Penelitian } \\
\text { kuantitatif } \\
\text { metode survei }\end{array}$ & $\begin{array}{l}\text { Instrumen } \\
\text { penilaian } \\
\text { pada aspek } \\
\text { kognitif }\end{array}$ & $\begin{array}{l}\text { Penilaian } \\
\text { pada aspek } \\
\text { kognitif } \\
\text { didasarkan } \\
\text { pada } \\
\text { penilaian } \\
\text { harian pada } \\
\text { perangkat } \\
\text { pembelajar } \\
\text { an }\end{array}$ \\
\hline $\begin{array}{l}\text { Victor, et al., } \\
\text { (2012) }\end{array}$ & - & $\begin{array}{l}\text { A systematic } \\
\text { review }\end{array}$ & - & $\begin{array}{l}\text { Penilaian } \\
\text { pada PJOK } \\
\text { dibagi } \\
\text { menjadi } \\
\text { penilaian } \\
\text { secara } \\
\text { formatif, } \\
\text { alternatif,a } \\
\text { utentik, } \\
\text { terintegrasi } \\
\text {, dan } \\
\text { terpusat }\end{array}$ \\
\hline
\end{tabular}

\section{PEMBAHASAN}

Hasil review jurnal Aji, Bastaman Sasmito dan M. E. Winarno (2016) didapatkan bahwa instrumen penilaian pada aspek pengetahuan mata pelajaran PJOK pada jenjang SMP direkomendasikan dalam bentuk multimedia interaktif dengan menggunakan program wondershare quiz creator. Akbar, M. Army., Rahmadi, dan Mulhim (2020) didapatkan bahwa instrumen penilaian aspek psikomotor dapat dilakukan melalui penilaian proyek dan penilaian kinerja yang dituangkan pada rubrik penilaian kinerja yang berisikan instruksi untuk melakukan gerakan berdasarkan kompetensi dasar yang di ajarkan. Artikel oleh Ashari, Lalu Hassan dan Djuniadi (2016) instrumen penilaian per assessment system merubah fungsi guru sebagai fasilitator dan motivator, sedangkan menempatkan siswa sebagai penilai. Peer assessment system berbentuk penilaian ceklis dengan empat skala yang dikemas dalam bentuk spread sheet. Penilaian tersebut dilengkapi dengan rubrik analitik dan pedoman penskoran dengan bentuk paper based. Garcia, et al., (2020) penggunaan penilaian peer assessment meningkatkan tingkat motivasi dan kepercayaan mengajar. Irwanto (2019) instrumen penilaian model CIPP didasarkan pada variabel context (berhubungan dengan kebutuhan dan tujuan pembelajaran), input (berhubungan dengan SDM sekolah dan sarpras), process (berhubungan dengan perencanaan, pelaksanaan, dan evaluasi pembelajaran), dan product (berhubungan dengan hasil belajar, meliputi afektif, psikomotor, dan kognitif). Ismail, Indri Astuti, dan Aloysius Mering (2018) didapatkan bahwa moodel CIPP didasarkan pada penilaian secara keseluruhan, mulai dari tujuan pembelajaran, sarana prasarana, proses pembelajaran hingga produk atau hasil dari pembelajaran. Iswanto (2017) Instrumen penilaian pada pelajaran PJOK dapat dilakukan pada aspek psikomotorik dengan memberikan tes praktek, sedangkan pada ranah kognitif dapat berupa soal essay. Juniarta, Aswin Try dan M. E. Winarno (2016) instrumen penilaian pelajaran PJOK dikemas dalam bentuk soal online dan direkomendasikan melalui program XAMPP. Kurniawan, Robby., M. E. Winarno., dan Wasis Djoko Dwiyogo (2018) melalui model countenance didasarkan pada tahap penggambaran (description) dan pertimbangan (judgement). Setiap tahap tersebut dibagi lagi menjadi tahapan pendahuluan (antecendent), proses (transaction), dan hasil (outcomes). Patria, Lalu Demung dan Djuniadi (2016) pada instrumen penilaian psikomotor berbasis IT 
dapat diaplikasikan pada materi PJOK lompat jauh. Salasiah, Rahmadi, dan Tri Irianto (2020) Penilaian pada aspek kognitif didasarkan pada penilaian harian pada perangkat pembelajaran. Victor, et al., (2012) Penilaian pada PJOK dibagi menjadi penilaian secara formatif, alternatif, autentik, terintegrasi, dan terpusat.

Banyak sekali penelitian terkait instumen penilaian mata pelajaran pendidikan jasmani olahraga dan kesehatan pada siswa SMP. Berdasarkan dari penjelasan di atas menunjukkan bahwa instrumen penilaian mata pelajaran pendidikan jasmani olahraga dan kesehatan pada siswa SMP terbagi menjadi aspek kognitif instrumen penilaiannya melalui pengamatan, aspek psikomotorik instrumen penilaiannya dapat menggunakan rubrik penilaian gerak, dan pada instrumen penilaian pada aspek afektif bisa dengan soal essay.

\section{KESIMPULAN}

Instrumen penilaian pendidikan jasmani olahraga kesehatan dapat dilakukan berdasarkan konteks yang ingin dinilai, aspek kognitif, psikomotorik, dan afektif. Instrumen penilaian pada aspek kognitif dapat berupa pengamatan, aspek psikomotorik berupa rubrik penilaian gerak, sedangkan aspek afektif dapat berupa soal essay.

\section{SARAN}

Penelitian review selanjutnya diharapkan mampu memberikan rekomendasi formula terkait instrumen penilaian pada masing-masing aspek. Formula yang direkomendasikan merupakan mampu menjadi acuan bagi setiap guru PJOK dalam melakukan penilaian.

\section{UCAPAN TERIMAKASIH}

Ucapan terimakasih kami sampaikan kepada pembimbing yang selalu memberikan bimbingan yang optimal sehingga artikel ini dpaat diselesaikan

\section{DAFTAR PUSTAKA}

Aji, Bastaman Sasmito dan M. E. Winarno. 2016. Pengembangan Instrumen Penilaian Pengetahuan Mata Pelajaran Pendidikan Jasmani Olahraga dan Kesehatan (PJOK) Kelas VIII Semester Gasal. Jurnal Pendidikan. Vol. 1 (7) 1449-1463.

Akbar, M. Army., Rahmadi, dan Mulhim. 2020. Instrumen Penilaian Harian Aspek Psikomotor Pendidikan Jasmani Olahraga dan Kesehatan. Stabilitas: Jurnal Pendidikan Jasmani dan Olahraga. Vol. 1(1) 56-62.

Arifin, Z. 2009. Evaluasi Pembelajaran. Rosdakarya.

Bandung: PT. Remaja

Ashari, Lalu Hassan dan Djuniadi. 2016. Pengembangan Instrumen Penilaian untuk Kerja dengan Model Peer Assesment System untuk Mata Pelajaran Penjasorkes pada Pokok Bahasan Permainan Bola Voli. Jurnal Kependidikan. Vol. 15 (1) 57 65.

Garcia, Daniel Bores., David Hortiguela A., Gustavo Gonzalez C., and Raul Barba M. 2020. Peer Assessment in Physical Education: A Systematic Review of The Last Five Years. Sustainbility. doi:10.3390/su12219233

Irwanto. 2019. Evaluasi Proses Belajar dan Pembelajaran dengan Model CIPP untuk Mata Pelajaran Penjasorkes di Sekolah Menengah Kejuruan Negeri 2 Kota Serang. Jurnal Kejaora. Vol. 4 (2) 6-13.

Ismail, Indri Astuti, dan Aloysius Mering. 2018. Evaluation of Learning Outcome Assesment System in Health and Sports Physical Education Subject in Junior High School. JETI : Journal of Education, Teaching, and Learning. Vol. 3 (2) 296-301.

Iswanto. 2017. Analisis Instrumen Ujian Formatif Mata Pelajaran Pendidikan Jasmani Olahraga dan Kesehatan Tingkat SMP. Jurnal Pendidikan Jasmani Indonesia. Vol.13 (2) 79-91. 
Juniarta, Aswin Try dan M. E. Winarno. 2016. Pengembangan Instrumen Penilaian Pengetahuan Mata Pelajaran Pendidikan Jasmani Olahraga dan Kesehatan (PJOK) Kelas XI Semester Gasal. Jurnal Pendidikan: Teori, Penelitian, dan Pengembangan. Vol. 1 (8) 16591664.

Kurniawan, Robby., M. E. Winarno., dan Wasis Djoko Dwiyogo. 2018. Evaluasi Pembelajaran Pendidikan Jasmani, Olahraga, dan Kesehatan pada Siswa SMA menggunakan Model Countenance. Jurnal Pendidikan: Teori, Penelitian, dan Pengembangan. Vol. 3 (10) 12531264.

Patria, Lalu Demung dan Djuniadi. 2016. Pengembangan Instrumen Penilaian Psikomotor Berbasis IT dalam Pembelajaran Penjasorkes Materi Lompat Jauh pada Siswa SMP. Jurnal Kependidikan Vol. 15 (1) 5156.

Poerwanti, E. 2001. Evaluasi Pembelajaran, Modul Akta Mengajar. Malang: UMM Press

Salasiah, Rahmadi, dan Tri Irianto. 2020. Instrumen Penilaian Harian Aspek Kognitif Pendidikan Jasmani Olahraa dan Kesehatan. Stabilitas: Jurnal Pendidikan Jasmani dan Olahraga. Vol. 1 (1) 25-31.

Víctor Manuel López-Pastor, David Kirk, Eloisa Lorente-Catalán, Ann Macphail and Doune Macdonald. 2012. Alternative Assessment In Physical Education: A Review of International Literature. Sport, Education And Society. DOI:10.1080/13573322.2012.71386 0. 